\title{
Design and modeling of an equalizer for fuel cell energy management systems
}

\author{
Milad Bahrami, Jean-Philippe Martin, Gaël Maranzana, Serge Pierfederici, Mathieu Weber, Farid \\ Meibody-Tabar, Majid Zandi
}

\begin{abstract}
During the lifespan of a Polymer Electrolyte Membrane Fuel Cell (PEMFC) system, some heterogeneities between the cells constituting the stack can appear. The voltage of one particular cell in a stack may decrease because of specific aging or local malfunctioning such as drying. As a result, more heat is generated in this cell leading to an increase in its temperature and thus an additional voltage loss. This snowball effect can result in the failure of the cell. Therefore, the lifetime of a PEMFC stack can be increased by applying energy management to its cells. Notable that the output voltage of a cell is lower than a stack. Hence, a high conversion ratio converter is necessary to implement such energy management. An efficient way to increase the output voltage is to connect the output capacitors of the converters such as the boosts in series. Ensuring the converters' controllability is a key point to implement energy management. In this paper, an equalizer system is proposed to ensure the controllability of the boost converters. The balancing speed and the low number of switches are the main advantages of this system. The validity of the proposed system is verified through simulation and experiments.
\end{abstract}

Index Terms-Controllability, converter, energy management, equalizer, Polymer Electrolyte Membrane Fuel Cell (PEMFC).

\section{INTRODUCTION}

$\mathrm{D}^{\mathrm{s}}$ URABILITY enhancement of Polymer Electrolyte Membrane Fuel Cells (PEMFCs) is one of the major challenges to enable the diffusion of this technology in the mass market. In a stack, different cells are electrically connected in series to increase the output voltage, whereas they are supplied with gas in parallel. The whole system lifetime strongly depends on each cell in such a connection. Therefore, energy management can have a key role to compensate for the faults that occurred in each cell. As an example, if the current production by one particular cell could be decreased to mitigate local flooding or could be increased to mitigate a local drying, the electrochemical stability of the stack would be improved. In the same way, if a faulty cell could be short-circuited, the stack may continue to operate in degraded mode and ensure the network reliability. Based on the new patent [1], the current of any number of cells in a single stack is accessible. As a result, the behavior of the cells in a stack can be checked and their fault can be compensated. However, a high voltage conversion ratio
DC-DC converter is required in this case, because the number of cells in series is decreased. Isolated or high voltage ratio stepup DC-DC converters can be used but the basic challenge is efficiency improvement [2], [3].

An efficient way to solve these issues is the series connection of the DC-DC converters' output capacitors. This solution leads to an increase the freedom degree in management and control of the PEMFCs. The basic drawback of this structure is the possibility of the controllability loss. For instance, if the input power of one cell becomes lower than the required amount, the voltage of the corresponding capacitor will decrease. In this case and assuming that the DC-DC converter is a boost converter, the controllability will be lost if the output voltage becomes lower than the input voltage. In such conditions, a voltage equalizer or a balancing system can ensure the controllability.

The equalizer in the literature can be categorized into two basic groups: with an auxiliary source and without auxiliary source [4]. The equalizers with auxiliary source use another source to compensate the lower voltage cells. These equalizers are not efficient, especially for embedded applications. As seen in Fig. 1, the equalizers without auxiliary sources, are categorized into two basic groups: dissipative and nondissipative equalizers [4]. Dissipative equalizers use resistance to decrease the voltage of the higher voltage cells. These equalizers waste much energy. Therefore, the efficiency is very low. However, the low cost, simple implementation, and small size are their advantages [5], [6]. The non-dissipative equalizers can be divided into three groups: capacitor based [6]-[12], converter based [4], [13]-[26] and other type equalizers [27], [28]. A control approach is usually adopted for switches of a specific structure to balance the voltages in the third group of equalizers.

A number of capacitors are connected to cells by a number of switches in the capacitor-based topologies. The cells are periodically connected to these capacitors, and this operation continues to the point where all the cells and capacitors reach the same voltage. These equalizers require a numerous amount of switches and they are not cost-effective for a large number of cells or high power applications. In addition, these equalizers can balance the voltages through several repeated operations. As a result, they need much time to balance the voltages. The maximum of the balancing current can be controlled by sizing the capacitor capacitances. Therefore, the high efficiency in balancing can be obtained independently of imbalance states 
[6]-[11]. The capacitors of each level of a multi-level converter were frequently connected to next or previous level capacitors by using the numerous amount of switch in [11]. In this topology, the switches and capacitors in the multi-level converter were used to balance the voltage of capacitors in each level without adding another device. To overcome the problem of the balancing time, the resonance phenomenon can be used. Using the resonance in such topologies, the balancing speed can be increased simultaneously with achieving the benefits of soft switching [12].

The converter based equalizer can be categorized into three groups: cell to stack equalizers [4], stack to cell equalizers [13], [19]-[25], stack to stack equalizers[26], and cell to cell equalizers [14]-[18].

A stack to cell equalizer with a flyback converter was used to equalize the voltage of series lithium-Ion batteries in [23]. A stack to stack equalizer was used in this topology to realize the modular approach.

A forward-flyback resonant inverter was used to send energy from the series cell to cells in [13]. A voltage multiplier circuit was connected to cells. This circuit is used two diodes for each cell to automatically select the lower voltage cells and send energy to them. The required amount of switches was minimized in this topology at a cost of lower efficiency due to the use of two diodes for each cell. In this topology, the number of switches is independent of the number of cells. Similar topology with a buck converter on the primary side of the transformer was used in [20] for photovoltaic application. The forward-flyback converter in [13] the proposed was divided by a bidirectional converter in [21]. Therefore, the design became more flexible and circuit implementation was simplified. In [24], a half-bridge converter was used on the primary side of a transformer to send energy from the series connected cell to lower voltage cells. A multi-stacked current doubler was connected to the secondary side of the transformer in connecting with cells. The number of diodes and inductances must be increased by increasing the number of cells. Since this topology can be implemented with two switches independent of cells number without a multi-winding transformer, the circuit design and implementation can be simplified. In [19], [22], an improved push-pull converter with clamping capacitor was used to send energy from the series cells to lower voltage cells. A multi-winding transformer was used in this topology and $\mathrm{H}$ bridge inverters were used in the secondary windings of the transformer. This topology needs to measure the voltage to drive the required $\mathrm{H}$-bridge inverters. The balancing current can be very high in this topology and as a result, the balancing time can be reduced.

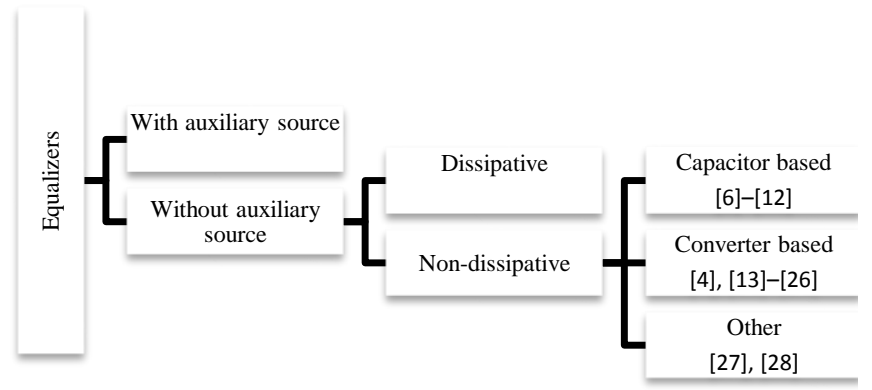

Fig. 1. Different types of equalizers.
For the battery applications, it is not necessary to have a large balancing current, because the voltage difference among cells slowly increases. Therefore, there is much time to balance the cells with the lower current to decrease the losses [6]. However, in such application of which the voltage balancing between output capacitors of DC-DC converters is required to ensure the controllability of the converters, the balancing time is the most important parameter. On the other hand, when the difference between cell voltages is very high, using the resonance can be dangerous for power electronic devices due to the high current peak. Regarding the possible inability of a cell or a set of cells in injecting the nominal power in a stack, a large difference between the output capacitor voltages is possible in the fuel cell applications. As a result, a new equalizer is proposed in this paper. The proposed equalizer can send energy to the lower voltage cells. This topology can quickly reach the steady-state condition by using a small number of switches and ensure the controllability in the worst conditions. The number of controlled switches in some converter-based equalizers depends on the cell numbers [4], [17]-[19], [22], [23], [26]. These equalizers are not effective in term of cost and volume. In the proposed equalizer, the number of controlled switches is independent of the cells number. In this paper, the performance of this equalizer is validated by the simulation and experimental results. A state space based model is also proposed that can be used for design purposes.

The rest of this paper is organized as follows: The principals of the proposed equalizer and the operation modes are described in Section II. The most important design considerations are also summarized in this section. In Section III, the simulation results are presented and compared with the theoretical results. The experimental results are provided in Section IV to validate the simulation results. Finally, conclusions are listed in Section V.

\section{Proposed equalizer}

As Mentioned before, a power electronic structure is required to manage the current of cells separately to increase the lifetime of the stack. Since the voltage of one cell or a small number of cells is very low, using a step-up converter is inevitable. In this case, the conventional boost converter is used for the purpose of simplicity. To further increase the output voltage, the output capacitors of boost converters are connected in series. Loss of controllability is possible in this case. To prevent this possibility, an equalizer is proposed. The proposed power electronic structure with the equalizer is shown in Fig. 2 where the classic boost converters are used to connect the cells to the DC bus. As seen in this figure, the energy can be transferred from the series capacitors to the lower voltage capacitors. The $\mathrm{H}$-bridge inverter can send the energy to even or odd numbered cells through the transformer. $C_{H}$ is a film capacitor at the input of the H-bridge inverter to stabilize the input voltage of this converter. The DC link voltage $\left(V_{d c}\right)$ is determined by the load requirements. Regarding the embedded application, the standard voltage of $48 \mathrm{v}$ is adopted for DC link voltage. It is assumed that the cells inside one stack are broken down into some group of cells with an identical number of cells. Furthermore, it is assumed that only one group of cells has a problem in one moment. In the worst condition, one group of 
cells can inject no power. As a result, the output capacitor voltage can be changed from zero to $16 \mathrm{v}$ in serial connection of four output capacitors. The DC link voltage is converted to the $\mathrm{AC}$ voltage on the primary side of the high-frequency transformer by the $\mathrm{H}$-bridge inverter. This $\mathrm{AC}$ voltage is shown by $V_{i n}$.

\section{A. Operation Modes}

In this section, the following assumptions are considered in the operation analysis for the purpose of simplicity:

1. All the switches and diodes are considered as the ideal devices.

2. Turn ratio for all secondary windings are the same and equal to $n=\frac{N_{2}}{k N_{1}}$ and $k$ is the coupling coefficient.

3. The coupling coefficient between the secondary windings is perfect.

4. The DC bus voltage is controlled to have a constant voltage of $V_{d c}$.

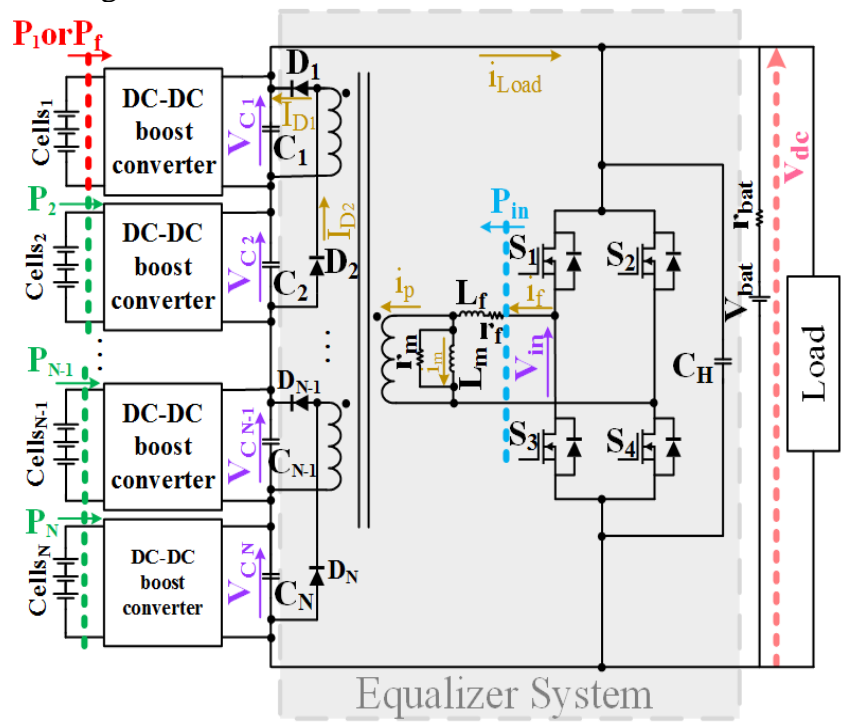

Fig. 2. Proposed equalizer topology.

The theoretic waveforms of the proposed equalizer are shown in Fig. 3 in steady state when $C_{1}$ and $C_{2}$ are the lower voltage capacitors between the even and odd-numbered cells respectively. Other cells have the same voltage. The switching commands of the H-bridge inverter are generated in such a way that a symmetrical square wave is imposed to the primary side of the transformer with variable duty cycle. Due to the windings polarity and the direction of the diodes in the circuit, the odd and even-numbered diodes can be naturally turned on in the positive and negative sections of the square wave, respectively. All the even-numbered/odd-numbered diodes are biased negatively when the input voltage of the transformer $V_{i n}$ is positive/negative. The diode corresponding to the capacitor, which has the lower voltage between even/odd-numbered capacitors, conducts the current when the negative/positive voltage appears on the primary side of the transformer. All the secondary windings will have the same voltage equal to the lower voltage capacitor when one diode starts to conduct. As a result, all the other diodes are reverse biased. The different operation modes of the proposed equalizer are shown in Fig. 4 when $C_{1}$ and $C_{2}$ are the lower voltage capacitors. This assumption is considered in order to investigate all the modes.

1) Mode 1 [ $t_{0}-t_{1}:$ Fig. 4 (a)]: before $t_{0}$ two switches $S_{1}$ and $S_{2}$ were on. At $t_{0}, S_{2}$ is turned off and $S_{4}$ is turned on. Therefore, the positive voltage is imposed on the primary side of the transformer. This voltage is induced in the secondary windings. This voltage leads to the reverse biased of the even-numbered diodes. Based on the reason mentioned above, only diode $D_{1}$, which connects to the lower voltage capacitor between odd-numbered capacitors, conducts current. As a result, the energy through the leakage inductance of the transformer is transferred to the capacitor $\mathrm{C}_{1}$. Therefore, the leakage current and voltage of $\mathrm{C}_{1}$ is increased. The derivative equations of different state variables are shown in (1).

$\left\{\begin{array}{l}L_{m} \frac{d i_{m}}{d t}=\frac{V_{C_{1}}+V_{d}}{n} \\ L_{f} \frac{d i_{f}}{d t}=V_{i n}-\frac{V_{C_{1}}+V_{d}}{n}-r_{f} i_{f} \\ C_{1} \frac{d V_{C_{1}}}{d t}=\frac{\left(i_{f}-i_{m}-\frac{-V_{C_{1}}+V_{d}}{n r_{m}}\right)}{n}-i_{\text {load }}+\frac{P_{F C_{1}}}{V_{C_{1}}} \\ C_{j} \frac{d V_{C_{j}}}{d t}=\frac{P_{F C_{j}}}{V_{C_{j}}}-i_{\text {load }} \quad j=2,3,4\end{array}\right.$

where $L$ is the inductance, $r$ is the resistance, $i$ is the current, $m$ and $f$ subscripts are used to indicate the magnetizing and leakage inductance or resistance, $V_{d}$ is the diode drop voltages, $V_{i n}$ is the input voltage at the primary side of the transformer, $\mathrm{V}_{\mathrm{C}_{\mathrm{j}}}$ is the voltage of $C_{j}, \mathrm{P}_{\mathrm{FC}_{\mathrm{j}}}$ is the injected power of $F C_{j}$, and $i_{\text {load }}$ is the load current.

2) Mode 2 [t $t_{1}-t_{2}:$ Fig. 4 (b)]: $S_{4}$ is turned off and $S_{2}$ is turned on as a synchronous rectifier in this mode. Therefore, the primary side of the transformer is short-circuited. The diode $\mathrm{D}_{1}$ continues to conduct but the current passing through it, which is proportional to the leakage current, is linearly decreased. The derivative equations in this mode are as follows:

$\left\{\begin{array}{l}L_{m} \frac{d i_{m}}{d t}=\frac{V_{C_{1}}+V_{d}}{n} \\ L_{f} \frac{d i_{f}}{d t}=-\frac{V_{C_{1}}+V_{d}}{n}-r_{f} i_{f} \\ C_{1} \frac{d V_{C_{1}}}{d t}=\frac{\left(i_{f}-i_{m}-\frac{V_{C_{1}}+V_{d}}{n r_{m}}\right)}{n}-i_{\text {load }}+\frac{P_{F C_{1}}}{V_{C_{1}}} \\ C_{j} \frac{d V_{C_{j}}}{d t}=\frac{P_{F C_{j}}}{V_{C_{j}}}-i_{\text {load }} \quad j=2,3,4\end{array}\right.$

The switching frequency is chosen in such a way that the diode $\mathrm{D}_{1}$ turns off and the leakage current is reached to the magnetizing current before the $t_{2}$. The differential equations are changed when the diode $D_{1}$ is turned off (after $t_{f}$ ) as follows:

$\left\{\begin{array}{l}L_{m} \frac{d i_{m}}{d t}=r_{m}\left(i_{f}-i_{m}\right) \\ L_{f} \frac{d i_{f}}{d t}=-r_{f} i_{f}-r_{m}\left(i_{f}-i_{m}\right) \\ C_{j} \frac{d V_{C_{j}}}{d t}=\frac{P_{F C_{j}}}{V_{C_{j}}}-i_{\text {load }} \quad j=1,2,3,4\end{array}\right.$ 


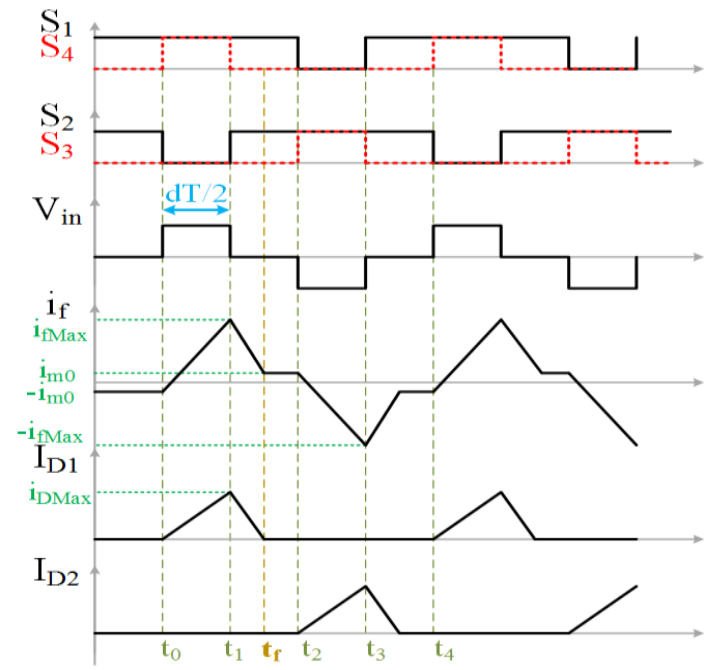

Fig. 3. Theoretical waveforms in steady-state operation of the proposed equalizer.

3) Mode 3 [ $t_{2}-t_{3}:$ Fig. 4 (c)]: $S_{1}$ is turned off and $S_{3}$ is turned on in this mode. The negative voltage appears on the primary side of the transformer. In other words, $V_{\text {in }}$ has a negative value. This mode like mode 1 has the same effect on the even numbered capacitors. The voltage of $\mathrm{C}_{2}$ is the lowest voltage between the even-numbered capacitors. Therefore, the diode $\mathrm{D}_{2}$ is turned on and the leakage current and the voltage of $\mathrm{C}_{2}$ starts to increase. The leakage current negatively increases. The derivative equations in this mode are as follows:

$\left\{\begin{array}{l}L_{m} \frac{d i_{m}}{d t}=-\frac{V_{C_{2}}+V_{d}}{n} \\ L_{f} \frac{d i_{f}}{d t}=V_{i n}+\frac{V_{C_{2}}+V_{d}}{n}-r_{f} i_{f} \\ C_{2} \frac{d V_{C_{2}}}{d t}=-\frac{\left(i_{f}-i_{m}+\frac{V_{C_{2}}+V_{d}}{n r_{m}}\right)}{n}-i_{\text {load }}+\frac{P_{F C_{2}}}{V_{C_{2}}} \\ C_{j} \frac{d V_{C_{j}}}{d t}=\frac{P_{F C_{j}}}{V_{C_{j}}}-i_{\text {load }} \quad j=1,3,4\end{array}\right.$

4) Mode 4 [ $\mathrm{t}_{3}-\mathrm{t}_{4}$ : Fig. 4 (d)]: This mode is similar to mode 2 with this difference that $S_{3}$ is turned off and $S_{1}$ is turned on. Before the diode $\mathrm{D}_{2}$ is turned off, the differential equations of the system are as follows:

$\left\{\begin{array}{l}L_{m} \frac{d i_{m}}{d t}=-\frac{V_{C_{2}}+V_{d}}{n} \\ L_{f} \frac{d i_{f}}{d t}=\frac{V_{C_{2}}+V_{d}}{n}-r_{f} i_{f} \\ C_{2} \frac{d V_{C_{2}}}{d t}=-\frac{\left(i_{f}-i_{m}+\frac{V_{C_{2}}+V_{d}}{n r_{m}}\right)}{n}-i_{\text {load }}+\frac{P_{F C_{2}}}{V_{C_{2}}} \\ C_{j} \frac{d V_{C_{j}}}{d t}=\frac{P_{F C_{j}}}{V_{C_{j}}}-i_{\text {load }} \quad j=1,3,4\end{array}\right.$

Then, the diode $\mathrm{D}_{2}$ is turned off and the differential equations of the system change as (4).

The power is transferred through the transformer to increase the voltage of lower voltage capacitors. Any losses in the transformer reduce the power that is received by lower voltage cells. The transformer leakage inductance can also affect its transmitting power by affecting its input current. Therefore, the transformer design has a key role in this topology.

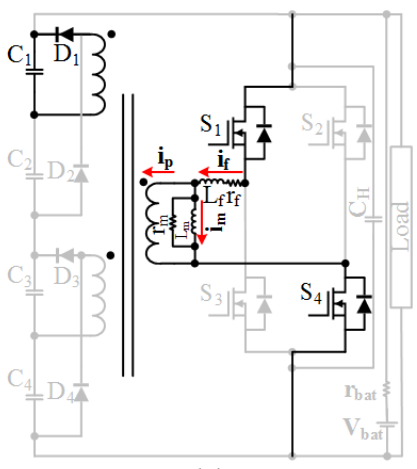

(a)

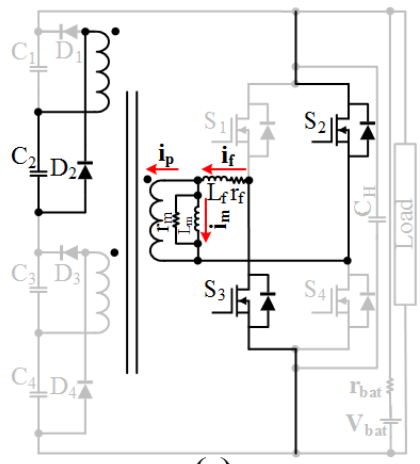

(c)

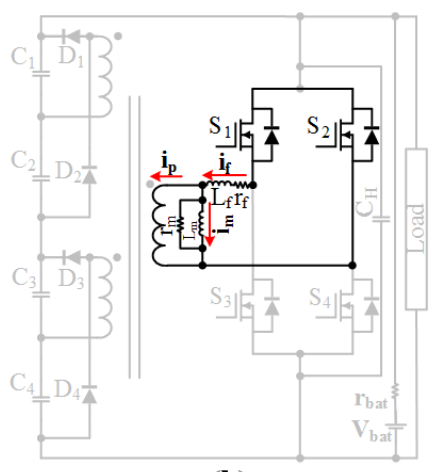

(b)

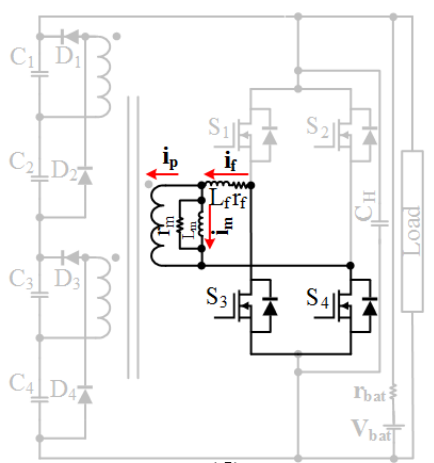

(d)
Fig. 4. Different operation modes of the proposed equalizer. (a) Mode 1: $t 0<t<t 1$. (b) Mode 2: $t 1<t<t 2$. (c) Mode3: $t 2<t<t 3$. (d) Mode 4: $t 3<t<t 4$.

\section{B. Design considerations}

The magnetizing inductance of the transformer must be maximized in order to reduce the magnetizing current. For instance, $\mathrm{L}_{\mathrm{m}}$ and $\mathrm{L}_{\mathrm{f}}$ of a core with two windings can be calculated by the following equation:

$$
\left\{\begin{array}{l}
L_{m}=k^{2} L_{1} \\
L_{f}=\left(1-k^{2}\right) L_{1}
\end{array}\right.
$$

Where $k$ is the coupling coefficient and $L_{l}$ can be calculated by:

$$
L_{1}=\frac{N^{2}}{\Re}
$$

$N$ is the number of turns and $\mathfrak{R}$ is the reluctance of the core. As seen in this equation, increasing the number of turns and decreasing the reluctance lead to increase the magnetizing inductance. Increasing the number of turns increases the volume of the transformer and, therefore, increase the hysteresis losses. Furthermore, increasing the number of turns also increases the wire length that leads to an increase of the wire resistance and, consequently, the copper losses. The reluctance is inversely proportional to the permeability. Hence, selecting a core with high permeability can make it possible to increase the magnetizing inductance with a lower volume. This also increases the leakage inductance. However, the leakage inductance affects the maximum transmitting power through the transformer in each cycle. This power is also the most important parameter in reducing the equalizing time. To obtain this power in steady state by considering the first group of cells as the faulty cells, the diode current can be used to calculate the transferred energy. Therefore, the transferred energy can be calculated as follows: 


$$
W_{e}=V_{C_{1}} \int_{t_{0}}^{t_{f}} i_{D}(t) d t=V_{C_{1}} \int_{t_{0}}^{t_{f}} \frac{i_{f}-i_{m}-\frac{V_{C_{1}}+V_{d}}{n r_{\mathrm{m}}}}{n} d t
$$

Where $W_{e}$ is the energy that is received by the faulted cell, $V_{C_{1}}$ is the voltage of the first capacitor, and $i_{D}$ is the corresponding diode current that is on. Based on Fig. 3, this equation can be solved by dividing its time interval into two intervals:

$$
W_{e}=\left(\int_{t_{0}}^{t_{1}} \frac{i_{f}-i_{m}}{n} d t+\int_{t_{1}}^{t_{f}} \frac{i_{f}-i_{m}}{n} d t-\frac{V_{C_{1}}+V_{d}}{n r_{m}}\left(t_{f}-t_{0}\right)\right)
$$

Assuming that the time constant of $L_{f} / r_{f}$ is much larger than $\mathrm{t}_{\mathrm{f}}-\mathrm{t}_{1}$, the magnetizing and leakage current functions can be obtained based on (1) in the interval $\left[\mathrm{t}_{0}, \mathrm{t}_{1}\right]$ as follows:

$$
\left\{\begin{array}{l}
i_{f}(t)=-i_{m 0}\left(1-\frac{t}{\frac{L_{f}}{r_{f}}}\right)+\frac{\sum_{j} V_{C_{j}}-\frac{V_{d}+V_{C_{1}}}{n}}{L_{f}} t \\
i_{m}(t)=-i_{m 0}+\frac{V_{d}+V_{C_{1}}}{n L_{\mathrm{m}}} t
\end{array}\right.
$$

Where $-i_{\mathrm{m} 0}$ is the magnetizing current at $t_{0}$. The magnetizing current value at $t_{\mathrm{f}}$ is equal to $i_{m 0}$. keeping the same assumption like (10) for the time constant of $L_{f} / r_{f}$, the magnetizing and leakage current functions can be obtained based on (2) in the interval of $\left[\mathrm{t}_{1}, \mathrm{t}_{\mathrm{f}}\right]$ as follows:

$$
\left\{\begin{array}{l}
i_{f}(t)=i_{m 0}\left(1-\frac{t-t_{1}}{\frac{L_{f}}{r_{f}}}\right)+\frac{V_{d}+V_{C_{1}}}{n L_{f}}\left(t_{f}-t_{1}\right)-\frac{V_{d}+V_{C_{1}}}{n L_{f}}\left(t-t_{1}\right) \\
i_{m}(t)=i_{m 0}+\frac{V_{d}+V_{C_{1}}}{n L_{\mathrm{m}}}\left(t-t_{f}\right)
\end{array}\right.
$$

Thus, by solving (9), a function for the transferred energy is obtained based on $L_{f}, L_{m}, m, V_{d}, t_{f}-t_{1}, t_{1}-t_{0}, V_{C_{1}}$, and the sum of the capacitor voltages. The interval $t_{1}-t_{0}$ is equal to $d T / 2$ where $T=1 / F$ and $F$ is the switching frequency of the H-bridge inverter, and $\mathrm{d}$ is its duty cycle. The value of $t_{f}-t_{1}$ can be calculated by writing the diode current equation over this interval $\left[t_{1}, t_{f}\right]$. The diode current can be obtained from integrating the following equation:

$$
\frac{d i_{D}}{d t}=\frac{d i_{f}}{d t}-\frac{d i_{m}}{d t}-\frac{V_{C_{1}}+V_{d}}{n r_{m}}
$$

Integration of this equation in the interval of $t_{0}-t_{1}$ and using (10), an equation is obtained for the maximum current value of the diode. Another equation for the maximum current of the diode can be obtained by integrating (12) in the interval of $t_{1}-t_{f}$ and using (11). The time $t_{f}-t_{l}$ can be calculated by solving these two equations.

To eliminate $i_{m 0}$ from the equations, the equation of magnetizing current over the whole interval $\left[t_{0}, t_{f}\right]$ can be used as follows:

$$
i_{m 0}=-i_{m 0}+\frac{V_{d}+V_{C_{1}}}{n L_{\mathrm{m}}}\left(t_{1}-t_{0}\right) \rightarrow 2 i_{m 0}=\frac{V_{d}+V_{C_{1}}}{n L_{\mathrm{m}}}\left(t_{1}-t_{0}\right)
$$

A function for the transferred energy is obtained by replacing (10) and (11) in (9) and using (12) and (13). The transmitting power through the transformer can be calculated with respect to this energy using the following equation:

$$
\begin{aligned}
& P_{e}=\frac{d V_{C_{1}}}{8 F^{2} n^{2}}\left(\frac{d F\left(n V_{d c}-\left(V_{C_{1}}+V_{d}\right)\right)}{L_{f}}-\frac{d F\left(V_{C_{1}}+V_{d}\right)}{L_{m}}-\right. \\
& \frac{16 F^{3} L_{m}\left(n r_{m} V_{d c}-2 L_{f}\left(V_{C_{1}}+V_{d}\right)\right)}{r_{m}\left(-4 F L_{f} L_{m}+4 F\left(L_{f}+L_{m}\right) r_{m}-d r_{f} r_{m}\right)}+\frac{d^{2} F r_{f}\left(-n r_{m} V_{d c}+2 L_{f}\left(V_{C_{1}}+V_{d}\right)\right)}{L_{f}\left(4 F L_{f} L_{m}-4 F\left(L_{f}+L_{m}\right) r_{m}+d r_{f} r_{m}\right)}- \\
& \frac{d\left(-4 F\left(L_{f}+L_{m}\right)+d r_{f}+d r_{f}\right)}{4 L_{f} L_{m}\left(4 F L_{f} L_{m}-4 F\left(L_{f}+L_{m}\right) r_{m}+d r_{f} r_{m}\right)^{2}\left(V_{C_{1}}+V_{d}\right)}\left(4 F L _ { m } r _ { m } \left(n V_{d c}-\left(V_{C_{1}}+\right.\right.\right. \\
& \left.\left.\left.\left.V_{d}\right)\right)+d r_{f} r_{m}\left(V_{C_{1}}+V_{d}\right)-4 F L_{f}\left(L_{m}+r_{m}\right)\left(V_{C_{1}}+V_{d}\right)\right)^{2}\right)
\end{aligned}
$$

As seen in this equation, the transferred power in steady state depends on the leakage and magnetizing inductances, capacitor voltages, frequency, duty cycle, iron losses, copper losses, and transformer turn ratio.

With the hypothesis that only one diode between oddnumbered cells/ even-numbered cells can be turned on at the positive/negative part of the input voltage of the transformer, the voltage difference can be calculated. In this case, just the first cell is supposed to have a problem. For this purpose, the Kirchhoff current law in steady state for each capacitor is written as follows:

$$
\left\{\begin{array}{l}
\frac{P_{1}+P_{e}}{V_{C_{1}}}-i_{\text {load }}=0 \\
\frac{P_{j}}{V_{C_{j}}}-i_{\text {load }}=0 \forall j \in\{2,3, \ldots, n\}
\end{array}\right.
$$

where $V_{C_{j}}$ is the voltage of capacitor number $\mathrm{j}, P_{j}$ is the supplied power by the cell number $\mathrm{j}$, and $i_{\text {load }}$ is the load current. The equation of load current is as follows:

$$
i_{\text {load }}=\frac{P_{\text {in }}}{V_{d c}}+\frac{V_{d c}-V_{\text {bat }}}{r_{\text {bat }}}
$$

where $V_{d c}$ is the DC bus voltage that is controlled to have a constant value, $V_{b a t}$ and $r_{b a t}$ is the voltage and the resistance of the power supply respectively that controls the DC bus voltage, and $P_{\text {in }}$ is the power injected to the equalizer system as follows:

$$
P_{\text {in }}=P_{e}+\frac{{\overline{V_{p}}}^{2}}{r_{m}}+r_{f}\left(\bar{I}_{f}\right)^{2}
$$

where $\bar{I}_{f}$ is the RMS value of leakage current that can be calculated using (10) and (11), and $\bar{V}_{p}$ is the RMS voltage on the primary side of the transformer that is the RMS value of $\frac{V_{d}+V_{C_{1}}}{\mathrm{n}}$ over the interval of $t_{f}$ $t_{0}$ in the switching period as follows:

$$
\left\{\begin{array}{l}
\bar{I}_{f}^{2}=\frac{1}{T} \int_{t_{0}}^{t_{f}}\left(i_{f}(t)\right)^{2} d t=\frac{1}{T}\left(\int_{t_{0}}^{t_{1}}\left(i_{f}(t)\right)^{2} d t+\int_{t_{1}}^{t_{f}}\left(i_{f}(t)\right)^{2} d t\right) \\
\bar{V}_{p}{ }^{2}=\frac{1}{T} \int_{t_{0}}^{t_{f}}\left(\frac{V_{d}+V_{C_{1}}}{n}\right)^{2} d t=\frac{\left(t_{f}-t_{0}\right)}{T}\left(\frac{V_{d}+V_{C_{1}}}{n}\right)^{2}
\end{array}\right.
$$

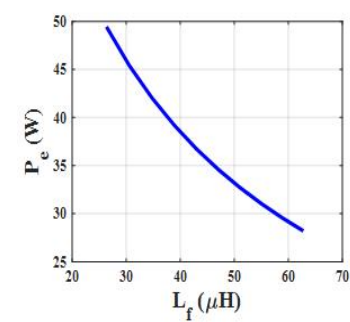

(a)

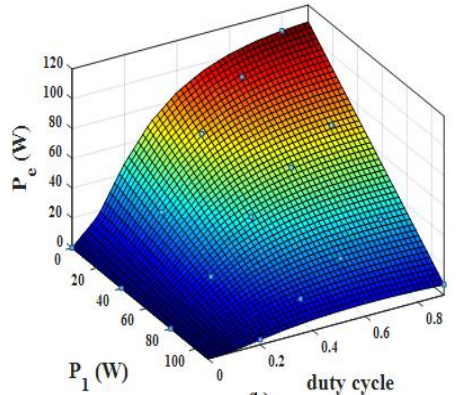

(b)
Fig. 5. The amount of transferred power through the transformer of the proposed equalizer in steady state based on: (a) Changes in the amount of leakage inductance when the duty cycle of $\mathrm{H}$-bridge inverter is equal to 0.4. (b) Changes in the amount of supplied power by the faulted cell and changes in the duty cycle.

By substituting (16) and (14) in (15), the resulting equations form a system of equations. $V_{C_{j}}$ can be determined by solving this system numerically. Then, $P_{e}$ can be calculated by (14). The results of these theoretical equations are shown in Fig. 5 by assuming the four capacitors in series, and that all PEMFCs can inject the rated power of $126 \mathrm{~W}$ except $\mathrm{FC}_{1}$ that injects no power. Other information is summarized in TABLE I. Therefore, the corresponding capacitor voltage $\left(V_{C_{1}}\right)$ is decreased. To investigate the impact of the leakage inductance on the transferred power to the lower voltage capacitor, the duty 
cycle of the H-bridge inverter is assumed to be 0.6 and the leakage inductance is changed. Using (14)-(16), the transferred power is calculated for different value of the leakage inductance. The amount of transferred power as a function of the leakage inductance is shown in Fig. 5 (a). As seen in this figure, the amount of power is decreased by increasing the leakage inductance. Thus, the leakage inductance should be minimized in one hand. A large leakage inductance is required to limit the overshoot of the current in another hand. Therefore, there must be a trade-off between the peak of current and maximum transferred power through the transformer.

To check the effectiveness of the proposed equalizer, it is assumed that the first group of cells cannot inject the nominal power. The injected power by the first cell is changed from zero to nominal power. The other groups of cells inject the nominal power. In this condition, the transferred power is calculated by changing the duty cycle of the H-bridge inverter based on (14)(16). The transferred power by changing the duty cycle of the H-bridge inverter for different value of first cells injected power is shown in Fig. 5 (b). As seen in this figure, the further reduction in injected power by the first group of cells can be compensated by increasing the duty cycle of the H-bridge inverter. In other words, the transferred power through the transformer is increased by increasing the duty cycle of the Hbridge inverter when the injected power of faulted cell was decreased.

To select a magnetic core based on the constraints mentioned above, the worst condition is taken into account. In this condition, one group of cells should be short-circuited. Thus, one group can inject no power while the other groups inject the nominal power. In this condition, the output voltage of the boost converter connected to the faulted cell decreased and the controllability is lost. The equalizer should send the power to this capacitor to ensure the controllability. The Leakage inductance of the transformer has an impact on the primary and secondary transformer side currents. Considering the first group of cells as the faulted cells, the first capacitor voltage is equal to zero in this condition. As a result and based on (10) and (13), the leakage current in transient conditions can be calculated as follows:

$$
i_{f}=\frac{\sum_{j} V_{C_{j}}}{L_{f}} t
$$

The DC link voltage is controlled to have a constant value of $48 \mathrm{~V}$ and based on Fig. 3, the maximum of the leakage current can be calculated as follows:

$$
i_{f \max }=\frac{48}{L_{f}} \frac{d T}{2}
$$

Using (10), (12), and (13), the maximum current of the diode can be calculated as follows:

$$
i_{D_{\max }}=\frac{48}{L_{f}} \frac{d T}{2 n}
$$

In the worst case, the duty cycle is equal to the maximum value of one. The maximum of the leakage current in the transient conditions for different value of the leakage inductance is shown in Fig. 6. As seen in this figure, the peak of the leakage current is very high. Indeed, a low-pass filter can cope with this problem and control the rate of duty-cycle change.

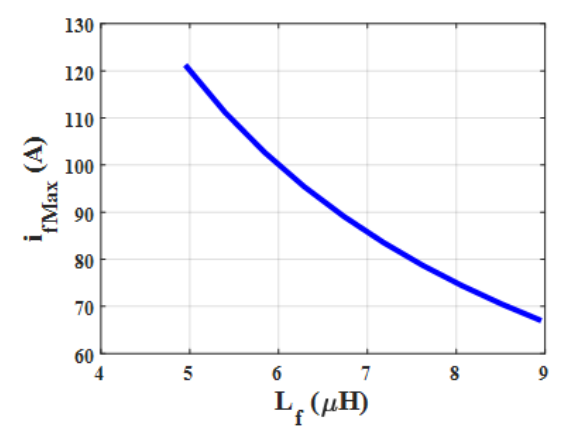

Fig. 6. Impact of the leakage inductance on the maximum of leakage current in transient conditions.

The leakage current in steady-state can be used to make a decision about the rating of the semiconductor devices. Considering a proportional gain to control the duty cycle of the H-bridge inverter in closed-loop, the maximum of the leakage and diode currents can be calculated by (10) and (12)-(16). These currents are shown in Fig. 7 by changing the leakage inductance of the transformer when the first group of cells can inject no power and other groups can inject the nominal power. As seen in this figure, if the leakage inductance is equal to $5 \mu \mathrm{F}$, the current rating of the H-bridge inverter switches should be very higher than $15 \mathrm{~A}$ and the current rating of the diodes should be higher than $60 \mathrm{~A}$. Therefore, there is a trade-off between the current rating of the semiconductor devices and the maximum power that can be transferred through the transformer.

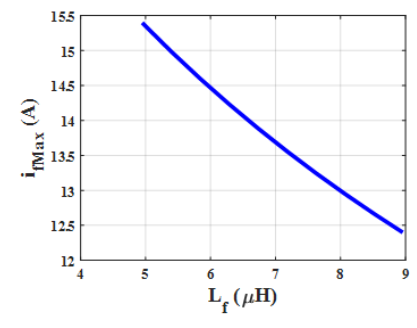

(a)

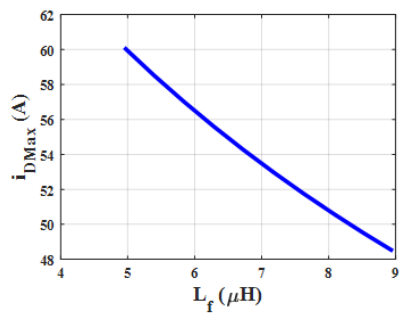

(b)
Fig. 7. Impact of the leakage inductance on a) the maximum of leakage current $b$ ) the maximum of the diode current in steady state.

The coupling coefficient of 0.99 is assumed based on previous experiences. Replacing (6) in (14) and using (15) and (16), the value of $L_{I}$ can be calculated to send the nominal power by the equalizer. Equation (7) can be used to select the magnetic core by knowing $L_{1}$. It is essential to minimize the volume of the transformer to reduce its losses. Therefore, the desired core can be chosen among the magnetic core in the market by using (7) and the classical equation of the minimum number of turns with the aim of minimizing the transformer volume. Considering these design constraints, the devices used to make simulation and obtain experimental results are shown in TABLE I.

\section{Simulation Results}

A simulation is made by four capacitors in series in Matlab Simulink to preliminary verify the validity of the proposed equalizer theories. For a precise study of the balancing system, the H-bridge inverter is controlled in the open-loop mode and duty cycle is set to 0.4. It is assumed that the PEMFCs connected to the first and second capacitors can inject the half of nominal power and the other cells inject the nominal power 
$(126 \mathrm{~W})$. The voltage and current waveforms on the primary side of the transformer for $\mathrm{d}=0.4$ are shown in Fig. 8. As seen in this figure, the current is linear and the power can be transmitted through the transformer. These results are also in agreement with the theoretical waveforms.
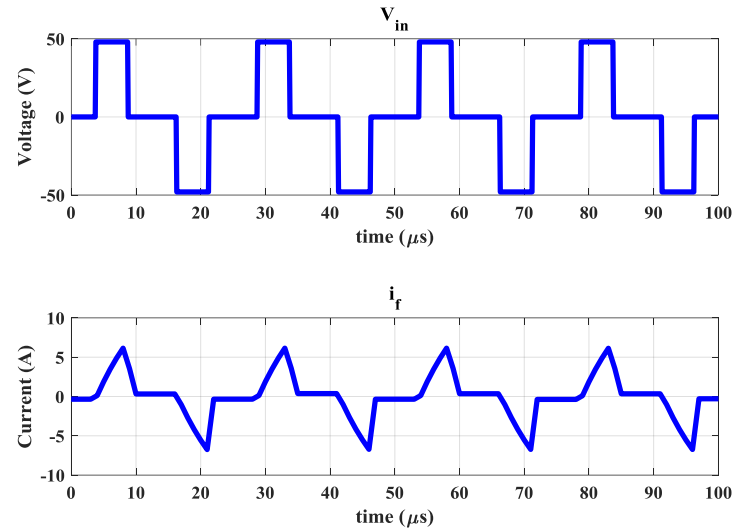

Fig. 8. Simulation results of voltage and current waveforms on the primary side of the transformer for $d=0.4$.

To control the duty cycle of the H-bridge inverter in closedloop, a simple proportional control is used. This closed-loop proportional control is implemented by comparing the average voltage of capacitors and their minimum voltage. As seen in Fig. 9, a low-pass filter is used in this control to limit the maximum current in transient conditions. The low pass filter is designed by considering the worst condition (short circuit of one group of cells) to ensure that the leakage current has no overshoot during transient conditions. The cut-off frequency of this filter is equal to $10 \mathrm{rad} / \mathrm{s}$. The proportional gain $(\mathrm{P})$ of this controller is set to 0.1 for the purpose of simulation and experimental results. The voltage changes of different capacitors with this closed-loop controller are shown in Fig. 10 when the cells inject nominal power except the first cell. The first cell is turned off and it can inject no power in this simulation.

\section{EXPERIMENTAL RESULTS}

For further verify the proposed balancing system and validation of the theoretical analysis and simulation, the experiments are conducted on a laboratory prototype as demonstrated in Fig. 11. dSPACE 1005 with FPGA board is used to receive the information and send the commands. Four programmable power supplies are used to emulate the PEMFCs. These power supplies are connected to four boost converters, the output capacitors of the boosts are connected in series. The component part number used in this prototype are listed in Table II. The proposed balancing system connects to these capacitors. It is notable that a planar transformer is built for this paper. Each winding turn of this transformer means a printed circuit board. On each printed circuit board, a copper line with the width of $21.5 \mathrm{~mm}$ and the thickness of $35 \mu \mathrm{m}$ is rotated in such a way that the circuits can be placed in the window of the magnetic core. This design is used to minimize the leakage inductance. The turn number of primary and secondary windings are shown in Table I.

To check the validity of the theoretical analysis and simulation, several experiments have been accomplished. First experiment conditions are similar to the first simulation. The cells inject nominal power except first and second cells. These cells inject the half of nominal power. The voltage and current waveforms on the primary side of the transformer for $\mathrm{d}=0.4$ are shown in Fig. 12. As seen in this figure, the results are in agreement with the simulation results and the power can be transferred to the first and second capacitors during the positive and negative part of the input voltage respectively.

The second experiment conditions are similar to the second simulation. The first power supply is turned off and as a result, it can inject no power. The other cells inject the nominal power. The voltage changes of different capacitors are shown in Fig. 13 when the duty-cycle of H-bridge inverter is controlled in closed-loop with the same parameter of simulation TABLE I

THE PARAMETER OF THE PROPOSED EQUALIZER

\begin{tabular}{|c|c|c|c|}
\hline Symbol & Unit & Value & Description \\
\hline $\bar{C}$ & $\mu F$ & 4700 & Electrochemical \\
\hline$A_{L}$ & $\mathrm{nH} /$ turns $^{2}$ & 12500 & Planar transformer core \\
\hline$N_{l}$ & turns & 4 & Primary winding turns \\
\hline$N_{2}$ & turns & 1 & Secondary winding turns \\
\hline$k$ & - & 0.99 & Coupling coefficient \\
\hline$F$ & $\mathrm{kHz}$ & 40 & Switching frequency of the H-bridge \\
\hline$R_{\text {Load }}$ & $\Omega$ & 7.5 & Resistive load \\
\hline$V_{F C}$ & $\mathrm{~V}$ & 6.3 & Nominal voltage of FCs \\
\hline$V_{C}$ & V & 12 & Nominal output voltages of boosts \\
\hline$C_{H}$ & $\mu F$ & 220 & Film capacitor \\
\hline$V_{d}$ & $\mathrm{~V}$ & 0.8 & Drop voltage of diodes \\
\hline
\end{tabular}

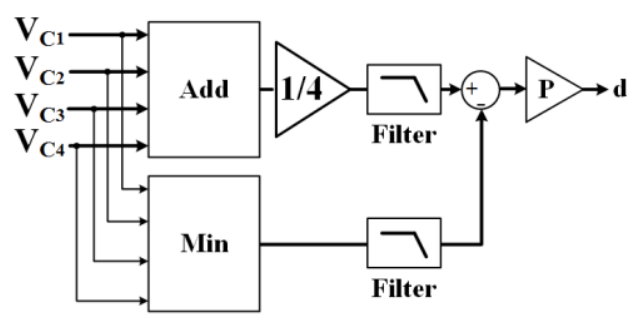

Fig. 9. Schematic diagram of the control method used to determine the duty cycle (d) of the H-bridge inverter.

To validate the proposed model for the design purpose, the capacitor voltages are measured when the first cell can inject the half of nominal power. In this experiment, the duty cycle is changed in the open-loop from 0.3 to 0.9. These voltages are also numerically calculated by (14)-(16). The output power of each boost converter is measured. These powers are used in these theoretical equations. The results of the experiment and theoretical equations are shown in Table III. In this table, the error $V_{C_{1}}$ is the relative error of the first capacitor voltage. In this table, the error is the root mean square of the relative errors as follows:

Error $=\sqrt{\sum_{j=1}^{4}\left(\frac{V_{C_{j_{t h}}}-V_{C_{j_{e x p}}}}{V_{C_{j_{t h}}}}\right)^{2}}$

where $V_{C_{j_{t h}}}$ and $V_{C_{j_{e x p}}}$ are respectively the theoretical and experimental voltage of the $\mathrm{j}^{\text {th }}$ capacitor. 


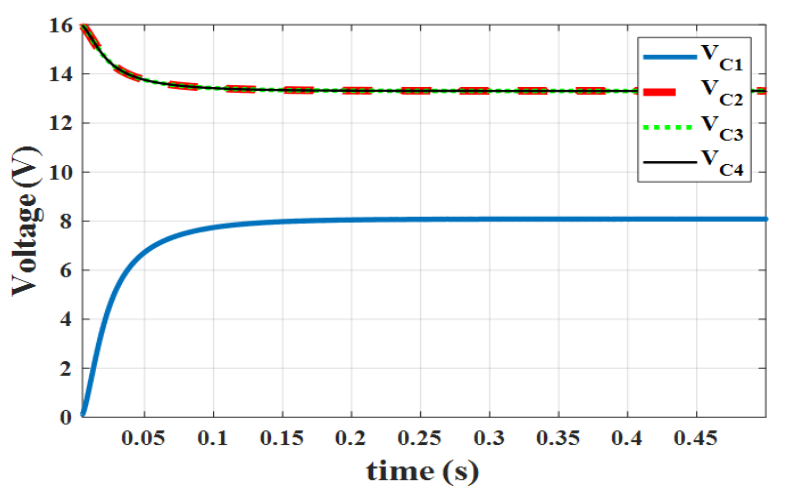

Fig. 10. Simulation results of the Output capacitor voltages in closedloop when the first group of cells injects no power.

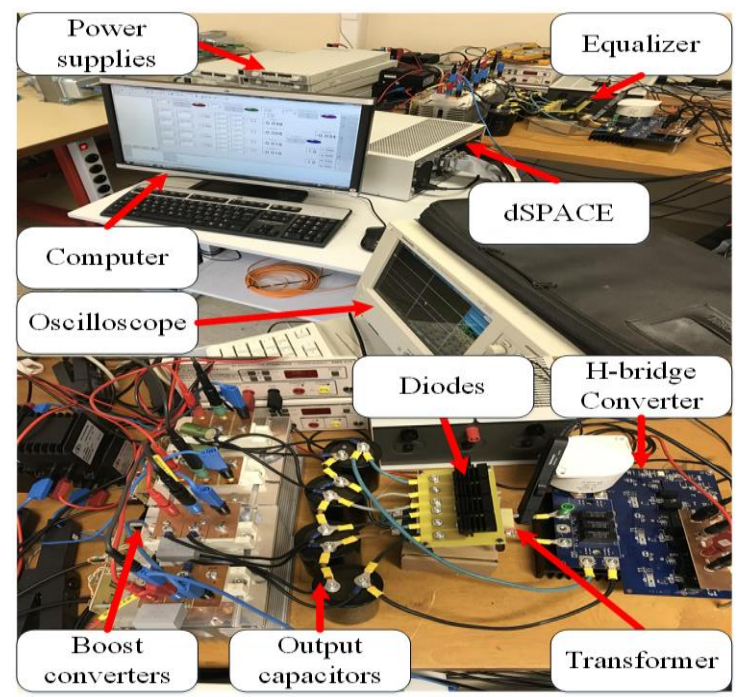

Fig. 11. Proposed equalizer test bench.

TABLE II

COMPONENT PART NUMBER FOR PROTOTYPE.

\begin{tabular}{|c|c|c|c|c|c|c|c|}
\hline & \multicolumn{3}{|c|}{ Component } & \multicolumn{4}{|c|}{ Part number } \\
\hline $\begin{array}{l}\mathrm{FC} \\
\text { Boost } \\
\text { converter }\end{array}$ & $\begin{array}{r}\mathrm{Sw} \\
\mathrm{Ca} \\
\mathrm{Dic} \\
\mathrm{Ma} \\
\mathrm{H}-\mathrm{t} \\
\text { switc } \\
\mathrm{Ca}\end{array}$ & $\begin{array}{l}\text { ver supp } \\
\text { uctance } \\
\text { tches } \\
\text { acitor } \\
\text { des } \\
\text { gnetic co } \\
\text { ridge } \\
\text { hes } \\
\text { acitor }\end{array}$ & & $\begin{array}{r}\text { TDK } \\
(1 \mathrm{mH} \\
\text { IGBT } \\
\text { Electr } \\
\text { DSS2 } \\
\text { B662 } \\
\text { SiC N } \\
\text { CCS050 } \\
\text { film }\end{array}$ & $\begin{array}{l}\text { ochemic } \\
\text { x121-00 } \\
\text { 5G Mat } \\
\text { IOSFET } \\
\text { M12CM } \\
220 \mu F\end{array}$ & $\begin{array}{l}\text { al }(4700 \\
45 B \\
\text { erial N8 } \\
2\end{array}$ & $\mu F)$ \\
\hline \multicolumn{8}{|c|}{$\begin{array}{c}\text { TABLE III } \\
\text { CAPACITOR VOLTAGES }(V) \text { COMPARISON BETWEEN THE THEORY AND } \\
\text { EXPERIMENT. }\end{array}$} \\
\hline Duty cycle & 0.3 & 0.4 & 0.5 & 0.6 & 0.7 & 0.8 & 0.9 \\
\hline$V_{C_{1 t h}}$ & 10.05 & 10.58 & 10.92 & 11.13 & 11.28 & 11.38 & 11.46 \\
\hline$V_{C_{2 t h}}$ & 12.72 & 12.54 & 12.43 & 12.35 & 12.31 & 12.27 & 12.25 \\
\hline$V_{C_{3 t h}}$ & 12.32 & 12.14 & 12.04 & 11.97 & 11.92 & 11.89 & 11.86 \\
\hline$V_{C_{t h h}}$ & 12.92 & 12.74 & 12.63 & 12.55 & 12.51 & 12.47 & 12.44 \\
\hline$V_{C_{1 e x}}$ & 10 & 10.5 & 10.9 & 11.1 & 11.3 & 11.3 & 11.4 \\
\hline$V_{C_{2 e x}}$ & 12.7 & 12.5 & 12.3 & 12.2 & 12.2 & 12.1 & 12.1 \\
\hline$V_{C_{3 e x}}$ & 12.4 & 12.1 & 12 & 12 & 12 & 12 & 12 \\
\hline$V_{C_{4 e x}}$ & 13 & 12.8 & 12.6 & 12.5 & 12.5 & 12.4 & 12.4 \\
\hline Error $(\%)$ & 1.04 & 1.00 & 1.14 & 1.33 & 1.13 & 1.89 & 1.81 \\
\hline Error $V_{C_{1}}(\%)$ & 0.50 & 0.76 & 0.18 & 0.27 & 0.18 & 0.70 & 0.52 \\
\hline
\end{tabular}

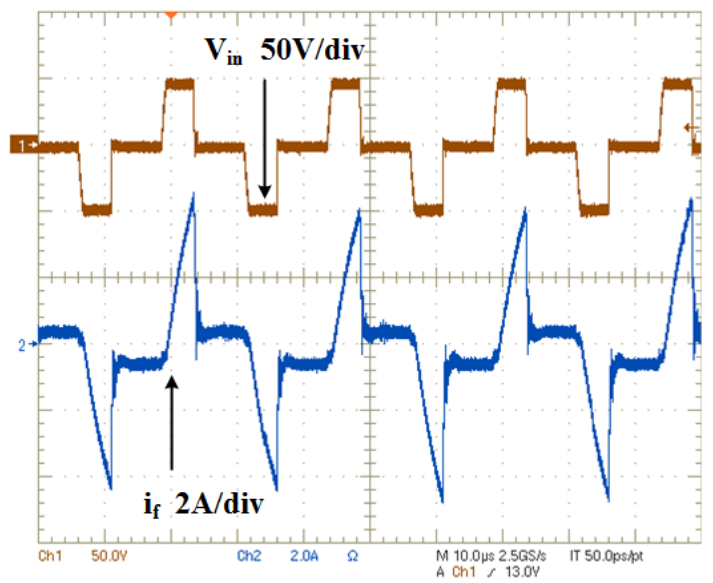

Fig. 12. Experimental waveforms of the current and voltage on the primary side of the transformer when first and second fuel cells inject the half of nominal power and duty cycle of H-bridge inverter is equal to 0.4 .

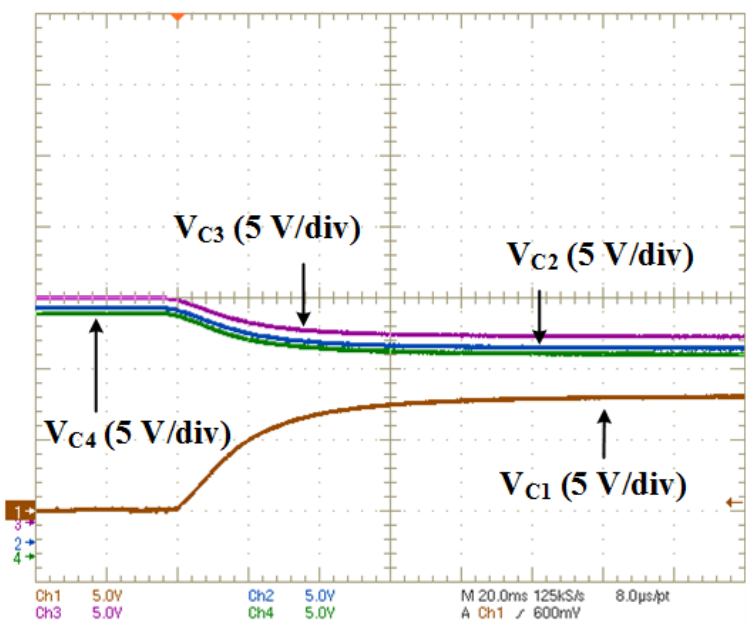

Fig. 13. Experimental results of the Output capacitor voltages when the first group of cells injects no power.

The main objective of the proposed equalizer system is to guarantee the controllability of DC-DC converters connected to fuel cells for applying energy management (Fig. 2). The drying and flooding conditions are the most critical conditions for the membrane of the PEMFC. In these conditions, the energy management system must function properly to compensate the faults. If one cell suffers from drying, it should be shortcircuited to produce more water by keeping constant gas flow rates. This leads to a decrease in gas stoichiometry for this particular cell and a consequent membrane humidification. On the contrary, no current should be generated by a cell in flooding conditions in order to let it dry. In other words, the power generated by the cell should be controlled near zero. In the following, it is assumed that the first cell experiences these conditions among four other healthy cells.

The capacitor voltages are shown in Fig. 14 (a) and the transformer voltage and current on the primary side are shown in Fig. 14 (b) in the flooding condition of the first PEMFC. As seen in these figures, the current of the first PEMFC cannot be set to zero before running the equalizer system. As seen in Fig. 14 , when the square wave voltage is supplied on the primary side of the transformer by the H-bridge inverter, the current of the first PEMFC reaches to zero after about $40 \mathrm{~ms}$ with the used 
parameters for the controller. Indeed, the boost converter connected to the first PEMFC will be controllable after this time. Furthermore, the capacitor voltage connected to the first PEMFC is increased and other capacitor voltages are decreased.

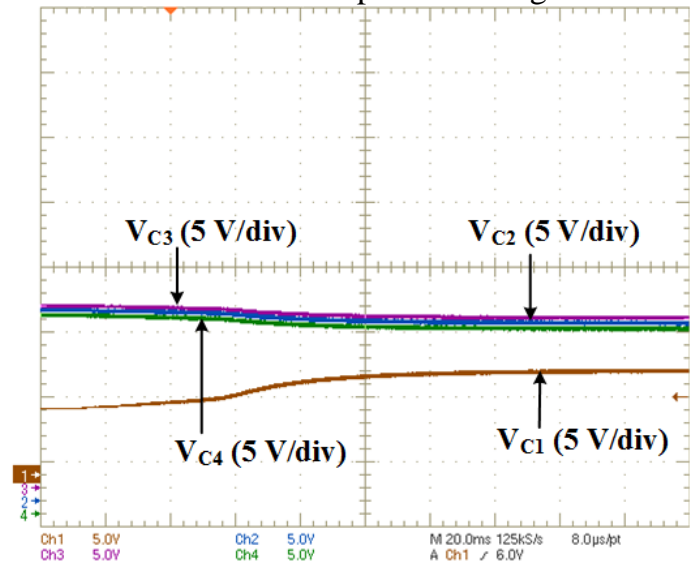

(a)

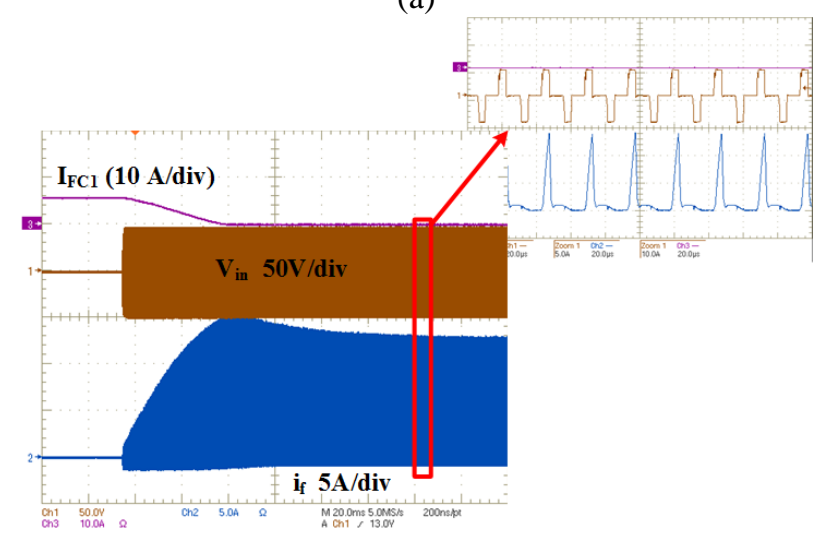

(b)

Fig. 14. Experimental results of the proposed equalizer during the flooding condition of the first cell. (a) Output capacitor voltages. (b) Voltage and current on the primary side of the transformer and current of the first cell.

The output capacitor voltages of the boost converters in the drying condition of the first PEMFC are shown in Fig. 15 (a). In this condition, the voltage and current on the primary side of the transformer are also shown in Fig. 15 (b). As seen in this figure, the first capacitor voltage is increased from zero to 8 volts but the short-circuit conditions are maintained for the first PEMFC. For this experiment, the maximum current of the power supply is limited to $20 \mathrm{~A}$.

\section{CONCLUSION}

In this paper, an equalizer based on the multi-winding transformer was proposed to ensure the controllability of boost converters in a series connection of their output capacitors.

This equalizer can be used to implement the PEMFC energy management system. The validation of the proposed system was investigated through the simulation and experimental results. The validity of the theoretical model was confirmed using the experimental results. Therefore, this model can be used to predict the behavior of the equalizer system. In other words, the theoretical equations can be used for sizing the system. The experimental results confirm the effectiveness of the equalizer system in maintaining the control ability of the boost converters when a cell is not able to supply the nominal power. The performance of the system was also evaluated in two critical conditions of the fuel cell operation. In both operation conditions (emulation of drying and flooding conditions), the controllability of the converter connected to the faulty cell is ensured by increasing its capacitor voltage.

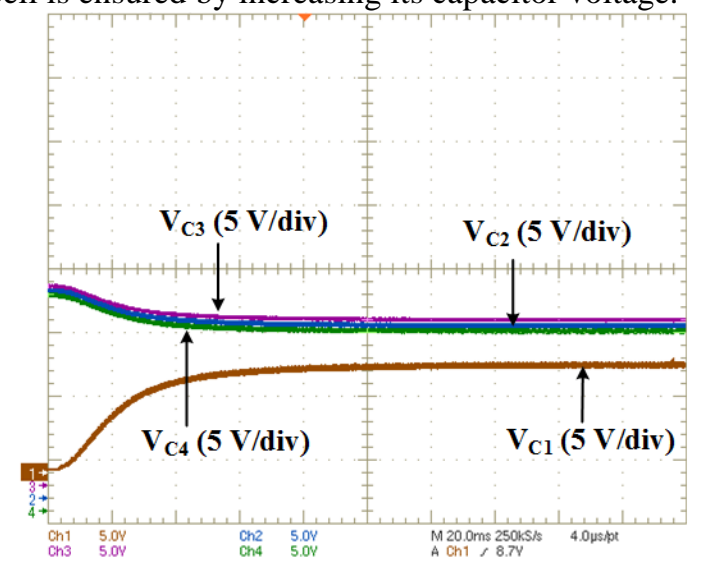

(a)

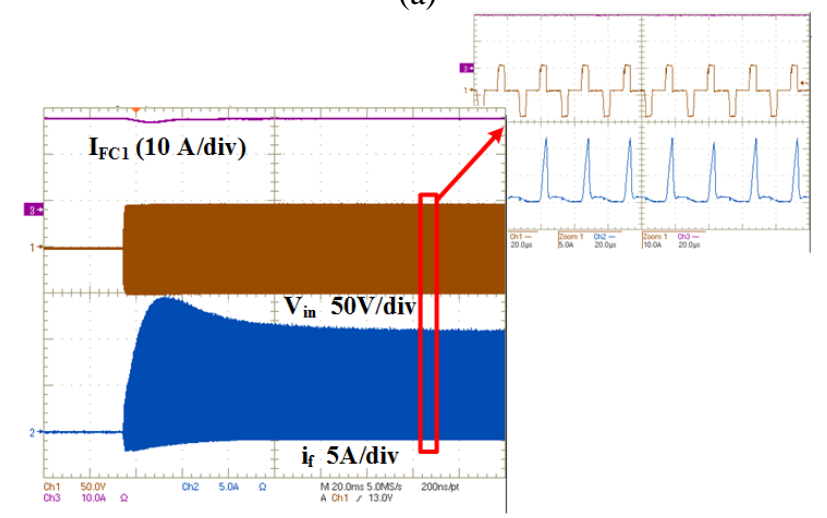

(b)

Fig. 15. Experimental results of the proposed equalizer during the drying condition of the first cell. (a) Output capacitor voltages. (b) Voltage and current on the primary side of the transformer.

\section{REFERENCES}

[1] G. Maranzana, S. Didierjean, J. Dillet, A. Thomas, and O. Lottin, "IMPROVED FUEL CELL. Patent n : WO/2014/060198.," 2014.

[2] T. Arunkumari and V. Indragandhi, "An overview of high voltage conversion ratio DC-DC converter configurations used in DC microgrid architectures," Renew. Sustain. Energy Rev., vol. 77, no. March, pp. 670-687, 2017.

[3] A. Shahin et al., "High Voltage Ratio DC - DC Converter for FuelCell Applications," IEEE Trans. Ind. Electron., vol. 57, no. 12, pp. 3944-3955, 2010.

[4] A. M. Imtiaz, S. Member, and F. H. Khan, “ Time Shared Flyback Converter' Based Regenerative Cell Balancing Technique for Series Connected Li-Ion Battery Strings," IEEE Trans. power Electron., vol. 28, no. 12, pp. 5960-5975, 2013.

[5] A. Hijazi, A. Sari, X. Lin-shi, and P. Venet, "Balancing Circuit New Control for Supercapacitor Storage System Lifetime Maximization," IEEE Trans. Power Electron., vol. 32, no. 6, pp. 4939-4948, 2017.

[6] Y. Shang, B. Xia, J. Yang, C. Zhang, N. Cui, and C. Mi, "A deltaStructured switched-Capacitor equalizer for series-Connected battery strings," 2017 IEEE Energy Convers. Congr. Expo. ECCE 2017, vol. 2017-Janua, no. 61633015, pp. 4493-4496, 2017.

[7] Y. Ye et al., "Topology, Modeling, and Design of SwitchedCapacitor-Based Cell Balancing Systems and Their Balancing Exploration," IEEE Trans. Power Electron., vol. 32, no. 6, pp. 44444454, 2017. 
[8] Y. Shang et al., "A Switched-Coupling-Capacitor Equalizer for Series-Connected Battery Strings," IEEE Trans. Power Electron., vol. 32, no. 10, pp. 7694-7706, 2017.

[9] M. Uno and A. Kukita, "PWM Converter Integrating Switched Capacitor Converter and Series-Resonant Voltage Multiplier as Equalizers for Photovoltaic Modules and Series-Connected Energy Storage Cells for Exploration Rovers," IEEE Trans. Power Electron., vol. 32, no. 11, pp. 8500-8513, 2017.

[10] Z. Shu, X. He, Z. Wang, D. Qiu, and Y. Jing, "Voltage balancing approaches for diode-clamped multilevel converters using auxiliary capacitor-based circuits," IEEE Trans. Power Electron., vol. 28, no. 5, pp. 2111-2124, 2013.

[11] X. Liu, J. Lv, C. Gao, and Z. Chen, "A Novel Diode-Clamped Modular Multilevel Converter With Simplified Capacitor VoltageBalancing Control," IEEE Trans. Ind. Electron., vol. 64, no. 11, pp. 8843-8854, 2017.

[12] Y. Ye and K. W. E. Cheng, "Analysis and Design of Zero-Current Switching Switched-Capacitor Cell Balancing Circuit for SeriesConnected Battery/Supercapacitor," IEEE Trans. Veh. Technol., vol. 67, no. 2, pp. 948-955, 2018.

[13] M. Uno and A. Kukita, "Single-Switch Single-Transformer Cell Voltage Equalizer Based on Forward - Flyback Resonant Inverter and Voltage Multiplier for," IEEE Trans. Veh. Technol., vol. 63, no. 9, pp. 4232-4247, 2014.

[14] Y. Chen, X. Liu, Y. Cui, J. Zou, and S. Yang, "A MultiWinding Transformer Cell-to-Cell Active Equalization Method for LithiumIon Batteries With Reduced Number of Driving Circuits," IEEE Trans. Power Electron., vol. 31, no. 7, pp. 4916-4929, 2016.

[15] Y. Shang, S. Member, B. Xia, S. Member, and C. Zhang, "An Automatic Equalizer Based on Forward- Flyback Converter for Series-Connected Battery Strings," IEEE Trans. Ind. Electron., vol. 64, no. 7, pp. 5380-5391, 2017.

[16] V. Yuhimenko et al., "Average Modeling and Performance Analysis of Voltage Sensorless Active Supercapacitor Balancer With Peak Current Protection," IEEE Trans. Power Electron., vol. 32, no. 2, pp. 1570-1578, 2017.

[17] K. Lee, S. Lee, Y. Choi, and B. Kang, "Active Balancing of Li-Ion Battery Cells Using Transformer as Energy Carrier," IEEE Trans. Ind. Electron., vol. 64, no. 2, pp. 1251-1257, 2017.

[18] Y. Lee and G. Cheng, "Quasi-Resonant Zero-Current-Switching Bidirectional Converter for Battery Equalization Applications," IEEE Trans. Power Electron., vol. 21, no. 5, pp. 1213-1224, 2006.

[19] L. Li, Z. Huang, H. Li, and H. Lu, "A high-efficiency voltage equalization scheme for supercapacitor energy storage system in renewable generation applications," Sustain., vol. 8, no. 6, 2016.

[20] M. Uno and A. Kukita, "Single-Switch Single-Magnetic PWM Converter Integrating Voltage Equalizer for Partially Shaded Photovoltaic Modules in Standalone Applications," IEEE Trans. Power Electron., vol. 33, no. 2, pp. 1259-1270, 2018.

[21] K. Yashiro and M. Uno, "Transformer-Less Bidirectional PWM Converter Integrating Voltage Multiplier-Based Cell Voltage Equalizer for Series-Connected Electric Double-Layer Capacitors," IEEE Trans. Power Electron., vol. 8993, no. c, 2018.

[22] L. Li, Z. Huang, H. Li, and J. Peng, "A rapid cell voltage balancing scheme for supercapacitor based energy storage systems for urban rail vehicles," Electr. Power Syst. Res., vol. 142, pp. 329-340, 2017. Z. Zhang, S. Member, H. Gui, S. Member, D. Gu, and Y. Yang, "A Hierarchical Active Balancing Architecture for Lithium-Ion Batteries," IEEE Trans. Power Electron., vol. 32, no. 4, pp. 27572768, 2017.

[24] M. Uno and A. Kukita, "String-to-Battery Voltage Equalizer Based on Half-Bridge Converter with Multi-Stacked Current Doublers for Series-Connected Batteries," IEEE Trans. Power Electron., 2018.

[25] T. Mizuno, T. Inoue, K. Iwasawa, and H. Koizumi, "A Voltage Equalizer Using Flyback Converter With Active Clamp," Circuits Syst. (APCCAS), 2012 IEEE Asia Pacific Conf., pp. 340-343, 2012.

[26] T. Anno and H. Koizumi, "Double-input bidirectional DC/DC converter using cell-voltage equalizer with flyback transformer," IEEE Trans. Power Electron., vol. 30, no. 6, pp. 2923-2934, 2015. J. Liu, J. Yang, J. Zhang, N. Zhao, and T. Q. Zheng, "Voltage Balance Control Based on Dual Active Bridge DC/DC Converters in a Power Electronic Traction Transformer," IEEE Trans. Power Electron., vol. 33, no. 2, pp. 1-1, 2017.

[28] H. Kang and H. Cha, "A New Nonisolated High-Voltage-Gain Boost
Converter With Inherent Output Voltage Balancing," IEEE Trans. Ind. Electron., vol. 65, no. 3, pp. 2189-2198, 2018.

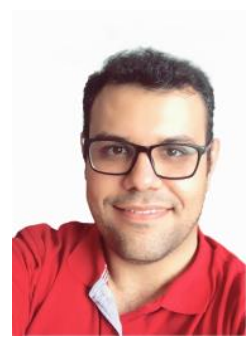

Milad Bahrami was born in Roodsar, Iran, in 1991. He received the B.Sc. degree in electrical engineering and M.Sc. degree in renewable energies engineering from Shahid Beheshti University, Tehran, Iran, in 2013 and 2016, respectively. He is currently working toward the Ph.D. degree with LEMTA, University of Lorraine, France.

His current research interests include Multi-vector microgrids, power converters design, stability analysis, control of electric hybrid systems, and clean energy sources.

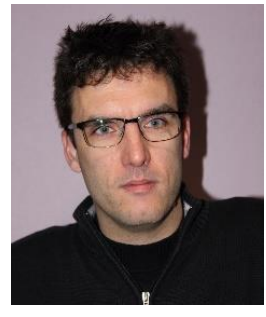

Jean-Philippe Martin received the graduation degree from the University of Nancy, Nancy, France, and the Ph.D. degree from the Institut National Polytechnique de Lorraine (INPL), Nancy, in 2003. Since 2004, he is an Assistant Professor at University of Lorraine and member of the LEMTA

since January 2018.

His research interests include DC and AC microgrid with centralized or decentralized control, multi-vector microgrid combining electrical, thermal and hydrogen vectors, stability study of distributed power systems, static converter architectures and their interactions with fuel cell and photovoltaic system.

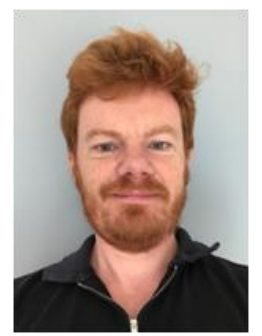

Gaël Maranzana obtained his Ph.D. degree in 2003 from the University of Lorraine. He was an assistant professor from 2005 to 2014 and then full professor.

His research focuses on transfer phenomena in electrochemical systems such as PEM fuel cells, PEM electrolyzers, and electrochemical

hydrogen compressors.

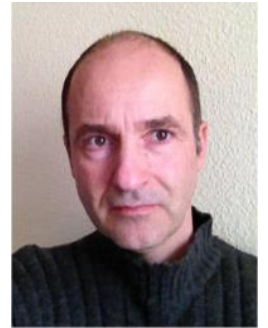

Serge Pierfederici received the Dipl.Ing. degree in electrical engineering from the Ecole Nationale Supérieure d'Electricité et de Mécanique (ENSEM) of Institut National Polytechnique de Lorraine (INPL), Nancy, France, in 1994, and the Ph.D. degree from the Institut National Polytechnique de Lorraine (INPL), Nancy, in 1998. Since 1999, he is working at the Lorraine University, where he is currently a Full Professor.

His research activities deal with the stability study of distributed power systems, the control of DC and AC microgrids and the design of power electronic converters for specific applications like fuel cell and electrolyzer systems. 


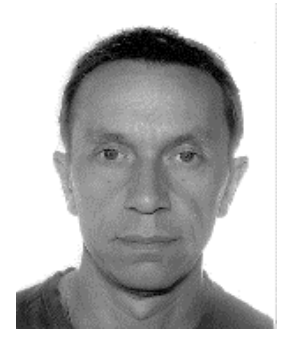

Mathieu Weber was born in Dieuze, France, in 1964. He received the Master 2 degree in electronic electrotechnic automatic from the University of Henry Poincaré, Nancy, France, in 1987.

$\mathrm{He}$ is currently working as the electronic engineer responsible for laboratory instrumentation at LEMTA, University of Lorraine, France. His research activities focus on energy conversion for the electrical engineering team of LEMTA.

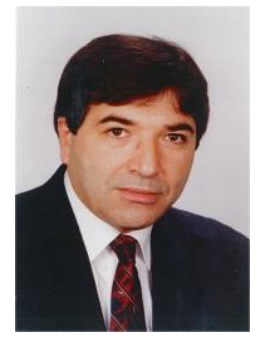

Farid Meibody-Tabar received the bachelor's degree in engineering from the Ecole Nationale d'Electricité et de Mécanique of Nancy, Nancy, France, in 1982, and the Ph.D. and Habilitation à diriger des recherches degrees from the Institut National Polytechnique de Lorraine (INPL), Nancy, in 1986 and 2000 , respectively.,Since 2000, he has been a Professor with INPL.

His current research interests include the supply, modeling, and control of electric machines and systems in normal and degraded operating modes.

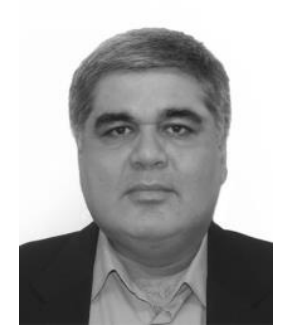

Majid Zandi received the B.Sc. degree in electrical engineering from Ferdowsi University, Mashhad, Iran, in 1991 and the M.Sc. degree from the Khajeh Nasir Toosi University of Technology, Tehran, Iran, in 1995. He received the Ph.D. degree from the Institut National Polytechnique de Lorraine (INPL), Nancy, France in 2010.

His research interests include the electric hybrid systems, electric vehicles, and clean \& renewable energy sources (e.g., fuel cells, wind \& solar energy and photovoltaic systems). He is the head of the Renewable Energies Department of SBU since 2011. 